\title{
Cyanobacteria in Coral Reef Ecosystems: A Review
}

\author{
L. Charpy, ${ }^{1}$ B. E. Casareto, ${ }^{2}$ M. J. Langlade, ${ }^{1}$ and Y. Suzuki ${ }^{2}$ \\ ${ }^{1}$ Mediterranean Institute of Oceanography (MIO), IRD, UR235 Center of Tahiti, BP 529, 98713 Papeete, French Polynesia \\ ${ }^{2}$ Graduate School of Science and Technology, Shizuoka University, 836 Ohya, Suruga-ku, Shizuoka 422-8529, Japan
}

Correspondence should be addressed to B. E. Casareto, casaretobe@aol.com

Received 15 June 2011; Revised 31 October 2011; Accepted 8 November 2011

Academic Editor: Horst Felbeck

Copyright (C 2012 L. Charpy et al. This is an open access article distributed under the Creative Commons Attribution License, which permits unrestricted use, distribution, and reproduction in any medium, provided the original work is properly cited.

\begin{abstract}
Cyanobacteria have dominated marine environments and have been reef builders on Earth for more than three million years (myr). Cyanobacteria still play an essential role in modern coral reef ecosystems by forming a major component of epiphytic, epilithic, and endolithic communities as well as of microbial mats. Cyanobacteria are grazed by reef organisms and also provide nitrogen to the coral reef ecosystems through nitrogen fixation. Recently, new unicellular cyanobacteria that express nitrogenase were found in the open ocean and in coral reef lagoons. Furthermore, cyanobacteria are important in calcification and decalcification. All limestone surfaces have a layer of boring algae in which cyanobacteria often play a dominant role. Cyanobacterial symbioses are abundant in coral reefs; the most common hosts are sponges and ascidians. Cyanobacteria use tactics beyond space occupation to inhibit coral recruitment. Cyanobacteria can also form pathogenic microbial consortia in association with other microbes on living coral tissues, causing coral tissue lysis and death, and considerable declines in coral reefs. In deep lagoons, coccoid cyanobacteria are abundant and are grazed by ciliates, heteroflagellates, and the benthic coral reef community. Cyanobacteria produce metabolites that act as attractants for some species and deterrents for some grazers of the reef communities.
\end{abstract}

\section{Cyanobacteria}

Cyanobacteria are oxy-photosynthetic bacteria. One of the characteristics of cyanobacteria is their thylakoids, the seats of photosynthesis, respiration, and in some species, molecular nitrogen fixation. One of the earliest signs of life on Earth was the formation of stromatolite reefs, which exist now as fossil structures in the oldest rocks known [1]. This cyanobacterial fossil record is among the oldest of any group of organism, possibly reaching back to 3500 million years (myr) ago. Throughout the succeeding 3000 myr, many shallow reefs arose and provided a habitat for cyanobacteria. Modern corals are a relatively recent phenomenon; indeed, scleractinian corals first appeared 230 myr ago in the Triassic [2]. Although cyanobacteria have been supplanted to an extent by eukaryotic algae on modern coral reefs, especially by the dinoflagellate Symbiodinium sp. (zooxanthellae) and coralline red and green algae, they play an essential role in the ecology of modern reefs. Nowadays, cyanobacteria are present in the benthos and plankton compartments of coral reef ecosystems. In this paper, we discuss the contribution of cyanobacteria to photosynthetic biomass and their role in coral reef ecosystems.

\section{Benthic Cyanobacteria}

2.1. Microbialites. Microbialites are organosedimentary deposits of trapped benthic microbes and detrital sediment and/or mineral precipitation [3]. Thus, microbialites may display various degrees of mineral induration. Based on their internal structure, Burne and Moore [4] divided microbialites into stromatolites characterized as sedimentary structures containing lithified laminae [5], thrombolites (clotted texture), cryptic microbialites (vague, mottled or patchy texture), oncolites (concentric lamination), and spherulitic microbialites (spherular aggregates).

Microbialites may represent a major structural component of the reef. Microbialites consist exclusively of millimetre- to centimetre-thick thrombolite crusts. In the barrier reef-edge of Tahiti, they may form $80 \%$ of the rock by volume and reflect at least 13,500 years of continuous reef formation. However, the development of microbialites in the cryptic niches of the reef framework ceased about 6000 years ago when the sea level approached its present level [6].

Soft, biscuit-shaped, internally finely laminated stromatolitic structures, with substantial quantities of fine grain (micritic) carbonate, have been discovered in a lagoon on 


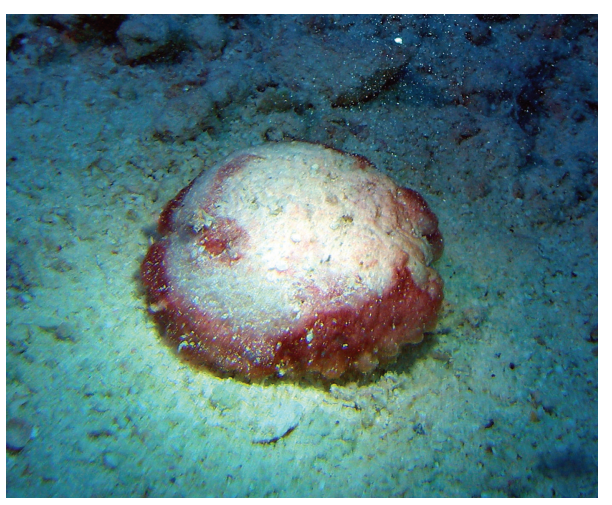

Figure 1: Stromatolitic structures built by filamentous, sheathed, non-heterocystous cyanobacteria recognized as two new species of Phormidium. Ahe lagoon, $25 \mathrm{~m}$ depth (Tuamotu Archipelago).

Tikehau atoll (Tuamotu Archipelago, French Polynesia) at depths of 15-23 m [7]. These modern stromatolites cover large areas of the lagoon floor and are especially numerous around patch reefs (Figure 1). They consist of filamentous, sheathed, non-heterocystous cyanobacteria recognized as two new species of Phormidium [3]. The constructional elements of carbonate precipitates fall into two categories characterized by distinctive forms and size ranges: micrometresized $(0.5-2.0 \mu \mathrm{m})$ mineral fibres, rounded $(0.1-0.2 \mu \mathrm{m})$ bodies, and grape-like clusters [3]. The growth of modern marine stromatolites represents a dynamic balance between sedimentation and intermittent lithification of cyanobacterial mats [8].

2.2. Endolithic Cyanobacteria. Carbonate skeletons of hermatypic corals harbour diverse populations of microboring organisms. Skeletons of live colonies are bored from the inside outward by Chlorophyta, while dead and denuded parts of coral skeletons are colonized at the surface and bored inward by a succession of euendoliths, starting with Chlorophyta and followed by cyanobacteria, to establish a stable Chlorophyta-dominated endolith community within 2 years [9].

The distribution of boring cyanobacteria generally depends on light level and depth; however some other factors may also influence their distribution. In Jamaica, in clear water, the boring cyanobacteria community structure changes below 20-30 m [10]. Boring cyanobacteria can also infest shells. In French Polynesia, infestations of cyanobacteria identified as Hyella, Mastigocoleus, and Plectonema destroy the commercially valuable shells of the black oyster Pinctada margaritifera [11].

In the carbonate cycle, cyanobacteria play an important and sometimes decisive role. Cycling of carbon and carbonate is linked to biological processes: some build up specific carbonate structures, some destroy carbonate substrates, and others do both simultaneously [12]. The photosynthetic activity of cyanobacteria, their extracellular polymeric substances, and possibly also their adherent heterotrophic bacteria are responsible for the construction of various carbonate structures and the ability to penetrate carbonate material [13]. The boring activity of euendoliths results in biological corrosion and disintegration of carbonate surfaces. Grazing organisms on carbonate surfaces colonized by epiand endolithic cyanobacteria produce specific biokarst forms and specific grains that can contribute to near-shore sedimentation [14]. Biological corrosion and abrasion together constitute bioerosion.

Endolithic phototrophs (cyanobacteria and Chlorophytes) are one of the major primary producers in dead coral substrates in a wide range of coral reef environments [15]. In an investigation of the photosynthetic activity and $\mathrm{N}_{2}$ fixation rates of coral rubble endoliths in fringing reefs at La Reunion Island (France) and Sesoko Island (Okinawa, Japan), the main endolith flora was composed of the cyanobacteria Hyella (cf.) caespitosa, Plectonema (cf.) terabrans, Mastigocoelus testarumin, and Scytonema (cf.) conchophyllum (the last two species with heterocysts). Their primary production rate varied seasonally between 1.6 and $4.8 \mu \mathrm{gC} \mu \mathrm{g} \mathrm{chl}^{-1} \mathrm{day}^{-1}$ and were comparable to those of scleractinian corals [16].

2.3. Symbiotic Cyanobacteria. Marine sponges can host a variety of cyanobacterial and bacterial symbionts. For example, the filamentous cyanobacterium Oscillatoria spongeliae is found in the sponge Dysidea on the Great Barrier Reef (Australia) and also in three species of Dysidea found around Guam [17]. In the Western Central Pacific reefs from Taiwan to the Ryukyu Archipelago, the encrusting sponge Terpios hoshinata is associated with unicellular cyanobacteria first described as Aphanocapsa raspaigellae [18, 19] and later reclassified using molecular tools as closely related to Prochoron sp. [20]. In the shallow waters of the Caribbean Sea, the encrusting sponges Terpios manglaris and T. belindae are associated with the cyanobacterium Hypheothrix sp. (Oscillatoriales, Schizotrichaceae) $[18,19]$. The sponge Terpios sp. aggressively competes for space by killing and overgrowing live corals and is responsible for devastating wide areas of coral reef. Phylogenetic analyses of 16S rRNA sequences of sponge-associated cyanobacteria have shown them to be polyphyletic. Many sequences are affiliated with Synechococcus and Prochlorococcus species [21, 22]. Cyanobacteria fill the cortical region of the sponge and penetrate inward into the choanosomal region [23]. Microbial symbionts may produce many of the pharmaceutically active compounds isolated from marine sponges $[24,25]$. These compounds can serve a variety of ecological functions, from predator and competitor deterrence and resistance to malignant microbial infections. Because cyanobacterial symbionts can also overgrow and kill their host sponge, it is not known whether sponges can actively regulate their symbiont populations [26].

2.4. Epiphytes. Benthic marine species of Phormidium with narrow trichomes and Plectonema are common epiphytes on cyanobacteria and algae. These organisms attach externally onto sheaths of other cyanobacteria, while Spirulina tend to crawl inside their sheaths. Small coccoid epiphytic cyanobacteria $(<0.8 \mu \mathrm{m}$ diameter $)$, which attach to sheaths of large 
Lyngbya majuscula $(>80 \mu \mathrm{m})$, illustrate the enormous cell size range of marine cyanobacteria [27].

Cyanobacteria are frequently observed as epiphytes of seagrass on the Great Astrolabe Reef, Fiji [28], and on the Great Barrier Reef, Australia [29], as well as epiphytes of algal turf on Virgin Island [30] in French Polynesia [31].

2.5. Microbial Mats. Microbial mats are associations of organisms dominated by cyanobacteria in association with photosynthetic bacteria, sulphur bacteria, and other microorganisms. They generally form flat, extensive mats of several millimetres in thickness on sand or mud. In coral reef ecosystems, microbial mats are found in soft muddy floors of lagoons comprised alternatively by different gliding filamentous cyanobacteria. The diversity of cyanobacterial mats inhabiting different environments has been the focus of several recent studies that applied molecular methods to natural populations. To explore the identity and distribution of natural populations of benthic marine cyanobacteria, polyphasic approaches have been used on Tikehau atoll (French Polynesia) [32], in New Caledonia [33], in the western Indian Ocean in Zanzibar (Tanzania) [34], in La Reunion Island, and in Okinawa [36]. These studies identified three types of organosedimentary structures that regularly occur on the lagoon floor: horizontally spreading mats, cobweb-like soft gelatinous masses, and hemispherical to spherical domes. These structures differ in appearance, species composition, mode of growth, and in their relationship to the substrate.

For example, on Tikehau Atoll, mats were dominated by Hydrocoleum cantharidosmum, H. coccineum, Spirulina subsalsa, Symploca hydnoides (Figure 2), and various species of Phormidium [32], whereas those in New Caledonia were dominated by heterocystous (Nodularia harveyana) and non-heterocystous (Hydrocoleum cantharidosmum, H. lyngbyaceum) [33]. In Page reef, Zanzibar, mats were dominated by filamentous non-heterocystous genera such as Lyngbya, Microcoleus, Spirulina, and Oscillatoria as well as by genera within Pseudanabaenaceae. Unicellular taxa were also represented, while heterocystous taxa were encountered only rarely [34]. In Broward County, Florida, USA, the blooms were dominated by Lyngbya polychroa [35]. Finally, on La Reunion Island and Sesoko Island, Anabaena sp. among heterocystous (Figure 3) and Hydrocoleum majus and Symploca hydnoides among non-heterocystous cyanobacteria occurred in microbial mats at both sites, whereas Oscillatoria bonnemaisonii and Leptolyngbya spp. occurred only on La Reunion Island, and Hydrocoleum coccineum and Phormidium laysanense dominated on Sesoko Island. Mats dominated by Hydrocoleum lyngbyaceum and Trichocoleus tenerrimus occurred at lower frequencies $[16,36]$.

Biological $\mathrm{N}_{2}$ fixation performed by cyanobacteria provides these organisms and microbial mat communities with a particular advantage when growing under $\mathrm{N}$-limited conditions, which are most common in marine environments. Biological $\mathrm{N}_{2}$ fixation by cyanobacteria appears to make a major contribution to $\mathrm{N}$ supply in coral reef ecosystems [36]. Not all cyanobacteria can fix atmospheric nitrogen.

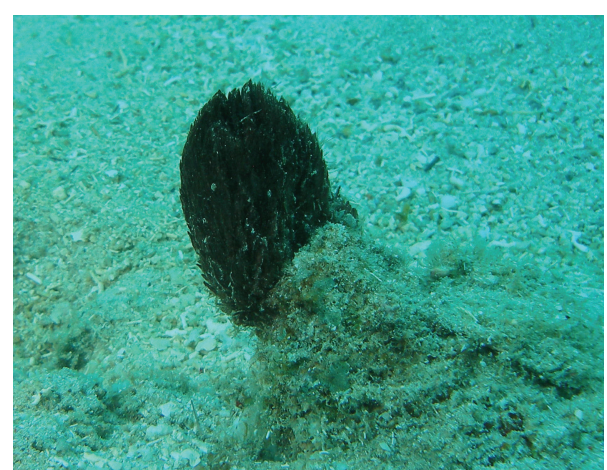

FIgURE 2: Tufts dominated by Symploca hydnoides in Mayotte lagoon at $10 \mathrm{~m}$ depth.

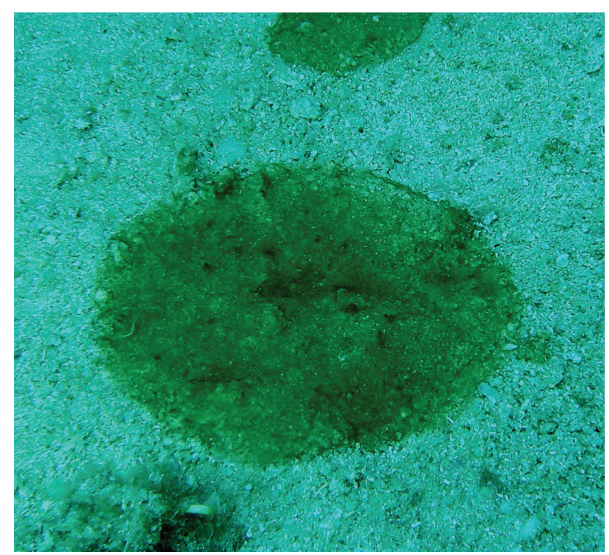

Figure 3: Cyanobacteria mats dominated by Anabaena sp. (heterocystous) in Mayotte lagoon at $14 \mathrm{~m}$ depth.

The process is oxygen-sensitive and energetically expensive, which constrains its implementation in oxygenic cyanobacteria; these bacteria separate the processes of carbon and nitrogen fixation either in space (i.e., heterocyst) or time [37].

The contribution of $\mathrm{N}_{2}$ fixation to that required for primary production is between $2 \%$ and $21 \%$ in Tikehau atoll lagoon [38] and New Caledonia [33]. Casareto et al. [16] compared $\mathrm{N}_{2}$ fixation rates of three different subenvironments (coral rubbles, microbial mats, and sandy bottoms) on La Reunion and Sesoko Islands. They found that $\mathrm{N}_{2}$ fixation rates of microbial mats are one order of magnitude higher than that of other subenvironments and can contribute up to $95 \%$ of their primary production [16].

2.6. Harmful Effects. Cyanobacteria are becoming increasingly prominent on declining reefs, as these microbes can tolerate strong solar radiation [39]. Changes in land use or seabird distribution that lead to alter dissolved organics, iron, and phosphorus input enhance proliferation of noxious blooms of cyanobacteria [40]. The production of deterrent secondary metabolites by benthic cyanobacterial and similar microbial assemblages facilitates the formation of cyanobacterial blooms on coral reefs [41].

Kuffner et al. [42] found evidence that algae and cyanobacteria use tactics beyond space occupation to inhibit coral recruitment. On reefs experiencing phase shifts or temporary 
algal blooms, the restocking of adult coral populations may be slowed due to recruitment inhibition by cyanobacteria, thereby perpetuating reduced coral cover and limiting coral community recovery. Cyanobacterial mats act as a poison for scleractinian corals and are able to kill live coral tissue [43]. About 30 diseases of corals have been recognised since they were first discovered more than 30 years ago. Little is known of the causes and effects of coral disease, although they can be caused by bacteria, fungi, algae, worms [44], and viruses [45-47].

Black band disease (BBD) of corals is caused by a pathogenic microbial consortium that exists as a horizontally migrating, laminated microbial mat. The consortium is structurally directly analogous to the cyanobacterial mats found in many illuminated, sulfide-rich benthic environments such as hot spring outflows and sediments of hypersaline lagoons, but is unique in that the entire mat community migrates across the surface of coral colonies, completely degrading coral tissue. BBD is one of a number of coral diseases believed to play an important role in the observed decline of coral reefs. The black band microbial consortium is dominated by Phormidium corallyticum [48] in the Caribbean, but other cyanobacteria species were described in Palau reefs [49] and in the Red Sea where a new cyanobacterium species, Pseudoscillatoria coralii gen. nov., sp. nov., dominates the BBD consortium on Favia sp. corals [50]. P. corallyticum can perform oxygenic photosynthesis in the presence or absence of sulfide but cannot conduct anoxygenic photosynthesis with sulfide as an electron donor. This species is not capable of fixing $\mathrm{N}_{2}$ [51]. Recent discoveries $[52,53]$ indicate that different species and strains of BBD cyanobacteria, which can occur in the same BBD infection, may contribute to BBD pathobiology by producing different types and amounts of toxins at different stages of the disease process. Understanding the interactions between coral larvae and benthic bloom-forming cyanobacteria may be important in managing coral reef ecosystems [54].

2.7. Benthic Cyanobacteria Grazing. Cyanobacteria are generally considered to be a poor food source due to toxicity, low nutritional value, or a morphology that makes ingestion difficult. Despite these factors, there are grazers that are adapted to feeding on cyanobacteria [55].

Lyngbya majuscula constitutes a major portion of the diet of a Pomacentrid damselfish on Davies Reef, Australia [56], and on Orpheus Island, Australia [57]. Many cyanobacteria, including species of Calothrix, Lyngbya, Oscillatoria, and Phormidium, have been found in the plate of fish Hemiglyphidodon plagiometopon [58].

During the life of the coral, the endoliths are protected from grazers, but in dead coral skeletons endolith cyanobacteria are exposed to grazing by molluscs, echinoderms and scarid fish [9]. The importance of epiphytic cyanobacteria as a food source for heterotrophs in coral reef ecosystems was also reported by Yamamuro [28]. Thacker et al. [59] found that coral reef fishes can learn to avoid defensive secondary metabolites, but that this learning does not occur when access to food is limited. This strategy may indicate that the effectiveness of the chemical defences of an alga or cyanobacteria is dependent on the state of the consumer and the defences of other prey in the environment. Thacker et al. [60] observed selected grazing on the cyanobacteria of Guam coral reefs, stressing the critical role of herbivory in determining coral reef community structure.

Some tropical benthic cyanobacteria are preferred foods for specialized consumers in the size range of mesograzers. Therefore, a diverse fauna may depend on cyanobacterial mats. Tropical mesograzers exploit considerably different food resources, with some species adapted to consume cyanobacterial mats. Benthic cyanobacteria may play important roles as food and shelter for marine consumers and may indirectly influence local biodiversity through their associated fauna [61, 62]. The cyanobacterial genus Lyngbya includes free-living, benthic, filamentous cyanobacteria that form periodic nuisance blooms in lagoons, reefs, and estuaries. Lyngbya spp. are prolific producers of biologically active compounds (metabolites). Lyngbya majuscule produces a wide variety of secondary metabolites, as well as lyngbyatoxin A (LTA). LTA production varies in different locations worldwide [63]. Specific metabolites produced by Lyngbya majuscula act as both feeding attractants to the specialist herbivore Stylocheilus longicauda, and as effective feeding deterrents to the generalist fishes [64]. One species, identified as Lyngbya cf. confervoides, produces a diverse array of bioactive peptides and depsipeptides [65].

Opisthobranchs may also play a role in top-down control of toxic cyanobacterial blooms, as was demonstrated for toxic Lyngbya by Capper and Paul [66].

Microbial mats can also be ingested by filter feeders. Identification of homoanatoxin-a from benthic marine cyanobacteria (Hydrocoleum lyngbyaceum) samples collected in Lifou (Loyalty Islands, New Caledonia) was recently reported [67]. This cyanobacterium was suspected to cause giant clam (Tridacna maxima) intoxications.

\section{Planktonic Cyanobacteria}

Planktonic cyanobacteria found in coral reef plankton are mainly filamentous and unicellular.

3.1. Planktonic Filamentous Cyanobacteria. Large blooms of Trichodesmium, a filamentous nitrogen-fixing cyanobacterium, are observed frequently in coral reef ecosystems [68]. They have been documented in the eastern Indian Ocean and western Pacific [69], in the central region of the Great Barrier Reef [70-73], in the Gulf of Thailand [74], and in the southwestern Tropical Pacific [75]. Trichodesmium spp. have been described to be nontoxic, sometimes toxic, or always toxic to a range of organisms [76-81]. Recent studies have provided unprecedented evidence of the toxicity of Trichodesmium spp. from the New Caledonia lagoon [82], demonstrating the possible role of these cyanobacteria in ciguatera fish poisoning.

Trichodesmium is the most well-studied marine $\mathrm{N}_{2}$-fixing organism and perhaps one of the most important. The rate of nitrogen fixation by Trichodesmium species in surface 
waters is close to $2 \mathrm{pmol} \mathrm{N}$ trichome $\mathrm{e}^{-1} \mathrm{~h}^{-1}$ [83]. It is difficult to quantify the importance of Trichodesmium diazotrophy because of the stochastic nature of the blooms. However, it is estimated that Trichodesmium contributes about 0.03$20 \%$ of the total $\mathrm{CO}_{2}$ fixation in the coastal surface waters of Tanzania [84].

The pelagic harpacticoid copepod Macrosetella gracilis is usually found in association with blooms of Trichodesmium in tropical and subtropical waters. This copepod is one of the few direct grazers of these often toxic cyanobacteria $[79,85]$.

The study of Villareal [86] in the Belizean barrier reef showed significant grazing of Trichodesmium by the coral reef community.

3.2. Planktonic Unicellular Cyanobacteria. Oligotrophic waters surrounding coral reef ecosystems and lagoons are dominated by the small coccoid unicellular cyanobacteria Synechococcus and Prochlorococcus [87-95]. In coral reef waters, Synechococcus has a size of $1 \mu \mathrm{m}$ and an abundance ranging from $10 \times 10^{3}$ to $500 \times 10^{3}$ cells $\mathrm{mL}^{-1}$, while Prochlorococcus has a size of $0.6 \mu \mathrm{m}$ and an abundance ranging from $10 \times 10^{3}$ to $400 \times 10^{3}$ cells $\mathrm{mL}^{-1}$.

The contribution of unicellular cyanobacteria to phytoplankton biomass and production varies according to the ecosystem. In Tuamotu lagoon (French Polynesia), Synechococcus is the predominant group in terms of abundance and carbon biomass and has the highest planktonic primary production among lagoons. As it is generally scarce in deep water with limited light availability, its biomass contribution is reduced in deep lagoons. In very shallow lagoons, no general trend has been observed, as the dominant group appears to depend on the water residence time within the lagoon [89-96]. In Tuamotu lagoon and Miyako Island (Okinawa) picoplankton primary production represents 65$80 \%$ of total phytoplankton production $[97,98]$.

In the Great Astrolabe Reef lagoon (Fiji), Synechococcus is the most abundant group (85-95\%), followed by picoeukaryotes $(5-10 \%)$ and Prochlorococcus $(<4 \%)$ [90]. Picoplankton primary production makes up $53.2 \%$ of the total phytoplankton production [90].

Ayukai [99] reported that on the Great Barrier Reef, the average abundance of cyanobacteria (Synechococcus) is 0.16$2.41 \times 10^{4}$ cells $\mathrm{mL}^{-1}$. Later, Crosbie and Furnas [92], using a flow cytometer, observed that Synechococcus was more abundant and had a greater biomass than Prochlorococcus at most inshore and mid-shelf sites in central regions $\left(17^{\circ} \mathrm{S}\right)$ and at all shelf sites in southern areas $\left(20^{\circ} \mathrm{S}\right)$ of Great Barrier Reef. Moreover, Synechococcus and Prochlorococcus abundance was better correlated with salinity, shelf depth, and chlorophyll $a$ concentration than with nutrient concentrations.

At Sesoko Island (Okinawa), Tada et al. [100] found that picoplankton dominated the phytoplankton community with an average contribution to the total chlorophyll- $a$ biomass of 52\%. At Miyako Island (Okinawa, Japan), the contribution of picophytoplankton to total phytoplankton biomass is $45-100 \%$ [101]. In another study, Ferrier-Pagès and Furla [96] found that the picophytoplankton contribution to total chlorophyll was $32-73 \%$. Prochlorococcus,
Synechococcus, and picoeukaryote abundance was on average $64 \pm 11,12 \pm 2$, and $4 \pm 0.7 \times 10^{3}$ cells $\mathrm{mL}^{-1}$, respectively. Their contribution to picoplankton biomass was 10, 49, and $41 \%$, respectively, and the contribution of picoplankton primary production to total phytoplankton production is 65\%. On Miyako Island, Okinawa (Japan), Synechococcus spp. represented $65 \%$ of the chlorophyll $(<3 \mu \mathrm{m}), 53 \%$ of autotrophic carbon, and $67 \%$ of the nitrogen [101]. In Mayotte (south-western Indian Ocean), particles $<10 \mu \mathrm{m}$ accounted for $74 \%$ of the chlorophyll- $a$ concentration and for $47 \%$ of the total living carbon [102].

In one study in New Caledonia's coral lagoon, unicellular diazotrophic cyanobacteria of $1-1.5 \mu \mathrm{m}$ were found along a nutrient gradient using whole-cell hybridization with specific Nitro 821 probes [103]. Their abundance ranged from 3 to 140 cells $\mathrm{mL}^{-1}$. These cells may contribute to $\mathrm{N}_{2}$ fixation (from the $<10 \mu \mathrm{m}$ size fraction) which was estimated to be $4.4-8 \mathrm{nmol} \mathrm{N}^{-1} \mathrm{~d}^{-1}$.

Very few studies have investigated grazing of unicellular cyanobacteria in coral reef waters $[101,102]$. In Tikehau lagoon (Tuamotu),González et al. [104] showed that phagotrophic nanoflagellates were the major grazers of picocyanobacteria. Ciliates and heterotrophic dinoflagellates appeared to be grazing mostly on nanoplankton, both autotrophic and heterotrophic cells, showing the important contribution of coccoid cyanobacteria to the microbial food web.

In Takapoto (Tuamotu), the grazing rates of $<200 \mu \mathrm{m}$ protozoa on cyanobacteria represented $74 \%$ of their growth rates [105]. In the lagoonal waters of the two largest atolls of French Polynesia (Rangiroa and Fakarava), 75\% of the cyanobacteria production was consumed by $<10 \mu \mathrm{m}$ fractions, equal to $0.05-0.5 \times 10^{4}$ cyanobacteria $\mathrm{mL}^{-1} \mathrm{~h}^{-1}$ [96]. In the water over a fringing coral reef at Miyako Island (Japan), 30-50\% of picocyanobacteria production was grazed by heterotrophic flagellates and ciliates, which themselves were grazed (50-70\% of the production) by higher trophic levels [101].

On Conch Reef, Florida Keys, sponges are a net sink for picocyanobacteria [106]. In the Gulf of Aqaba, Red Sea, measurements of depletion of phytoplankton cells and pigments over coral reefs have revealed that Synechococcus contributes $>70 \%$ of the total depleted carbon in summer. The grazing of cyanobacteria appears to be an important component of benthic-pelagic coupling in coral reefs [102, 107]. Another study by Yahel et al. [108] demonstrated that sponges removed significant amounts of picocyanobacteria but suggested that DOC may play a major role in the trophic dynamics of coral reefs. In Caribbean coral reef communities, gorgonian corals do not appear to graze significantly on picocyanobacteria [109].

\section{Conclusions}

Cyanobacteria are ubiquitous in coral reef ecosystems:

(i) as a part of the reef (Microbialites),

(ii) inside (endoliths) and above (epiliths and epiphytes) the coral reef, 
(iii) as symbionts of sponges,

(iv) covering soft bottoms as microbial mats,

(v) in the water column.

In addition, they have the following.

(i) They help build and erode the reef.

(ii) They are important primary producers.

(iii) They represent an organic source for planktonic and benthic heterotrophic organisms.

(iv) They enrich the ecosystem with nitrogen.

\section{Acknowledgments}

This work was supported by the Institute of Research for Development (IRD) and by grants from the Ocean Development Sub-Committee of France-Japan S\&T Cooperation, Mitsubishi cooperation, the Ministry of Education, Science, Sport, and Culture of Japan.

\section{References}

[1] S. M. Awramik, J. W. Schopf, and M. R. Walter, "Filamentous fossil bacteria from the Archean of Western Australia," Precambrian Research, vol. 20, no. 2-4, pp. 357-374, 1983.

[2] J. E. N. Veron, Corals in Space and Time: The Biogeography and Evolution of the Scleractinia, UNSW Press, Sydney, Australia, 1995.

[3] S. Sprachta, G. Camoin, S. Golubic, and T. Le Campion, "Microbialites in a modern lagoonal environment: Nature and distribution, Tikehau atoll (French Polynesia)," Palaeogeography, Palaeoclimatology, Palaeoecology, vol. 175, no. 1-4, pp. 103-124, 2001.

[4] R. V. Burne and L. S. Moore, "Microbialites: organosedimentary deposits of benthic microbial communities," Palaios, vol. 2, no. 3, pp. 241-254, 1987.

[5] T. F. Steppe, J. L. Pinckney, J. Dyble, and H. W. Paerl, "Diazotrophy in modern marine Bahamian stromatolites," Microbial Ecology, vol. 41, no. 1, pp. 36-44, 2001.

[6] G. F. Camoin, P. Gautret, L. F. Montaggioni, and G. Cabioch, "Nature and environmental significance of microbialites in Quaternary reefs: the Tahiti paradox," Sedimentary Geology, vol. 126, no. 1-4, pp. 271-304, 1999.

[7] C. Charpy-Roubaud, T. Le Campion, S. Golubic, and G. Sarazin, "Recent cyanobacterial stromatolites in the lagoon of Tikehau Atoll (Tuamotu Archipelago, French Polynesia): preliminary observations," in Marine Cyanobacteria, L. Charpy and A. W. D. Larkum, Eds., vol. 19, pp. 121-125, Monaco Musée Océanographique, Monaco, 1999.

[8] R. P. Reid, P. T. Visscher, A. W. Decho et al., "The role of microbes in accretion, lamination and early lithification of modern marine stromatolites," Nature, vol. 406, no. 6799, pp. 989-992, 2000.

[9] T. Le Campion Alsumard, S. Golubic, and P. Hutchings, "Microbial endoliths in skeletons of live and dead corals: Porites lobata (Moorea, French Polynesia)," Marine Ecology Progress Series, vol. 117, no. 1-3, pp. 149-158, 1995.

[10] C. T. Perry and I. A. Macdonald, "Impacts of light penetration on the bathymetry of reef microboring communities: implications for the development of microendolithic trace assemblages," Palaeogeography, Palaeoclimatology, Palaeoecology, vol. 186, no. 1-2, pp. 101-113, 2002.

[11] L. Mao Che, T. Le Campion-Alsumard, N. Boury-Esnault, C. Payri, S. Golubic, and C. Bézac, "Biodegradation of shells of the black pearl oyster, Pinctada margaritifera var. cumingii, by microborers and sponges of French Polynesia," Marine Biology, vol. 126, no. 3, pp. 509-519, 1996.

[12] J. Schneider and T. Le Campion-Alsumard, "Construction and destruction of carbonates by marine and freshwater cyanobacteria," European Journal of Phycology, vol. 34, no. 4, pp. 417-426, 1999.

[13] G. Arp, A. Reimer, and J. Reitner, "Calcification in cyanobacterial biofilms of alkaline salt lakes," European Journal of Phycology, vol. 34, no. 4, pp. 393-403, 1999.

[14] J. Schneider and H. Torunski, "Biokarst on limestone coasts, morphogenesis and sediment production," Marine Ecology, vol. 4, no. 1, pp. 45-63, 1983.

[15] A. Tribollet, C. Langdon, S. Golubic, and M. Atkinson, "Endolithic microflora are major primary producers in dead carbonate substrates of Hawaiian coral reefs," Journal of Phycology, vol. 42, no. 2, pp. 292-303, 2006.

[16] B. E. Casareto, L. Charpy, M. J. Langlade et al., "Nitrogen fixation in coral reef environments," in Proceedings of the 11th International Coral Reef Symposium, vol. 2, pp. 896-900, Fort. Lauderdale, Fla, USA, 2008.

[17] R. Hinde, F. Pironet, and M. A. Borowitzka, "Isolation of Oscillatoria spongeliae, the filamentous cyanobacterial symbiont of the marine sponge Dysidea herbacea," Marine Biology, vol. 119, no. 1, pp. 99-104, 1994.

[18] K. Rutzler and K. Muzik, "Terpios hoshinata, a new cyanobacteriosponge threatening Pacific reefs," Scientia Marina, vol. 57, no. 4, pp. 395-403, 1993.

[19] K. Rutzler and K. P. Smith, "The genus Terpios (Suberitidae) and new species in the "Lobiceps" complex," Scientia Marina, vol. 57, no. 4, pp. 381-393, 1993.

[20] S.-L. Tang, M.-J. Hong, M.-H. Liao et al., "Bacteria associated with an encrusting sponge (Terpios hoshinota) and the corals partially covered by the sponge," Environmental Microbiology, vol. 13, no. 5, pp. 1179-1191, 2011.

[21] L. Steindler, D. Huchon, A. Avni, and M. Ilan, "16S rRNA phylogeny of sponge-associated cyanobacteria," Applied and Environmental Microbiology, vol. 71, no. 7, pp. 4127-4131, 2005.

[22] P. M. Erwin and R. W. Thacker, "Cryptic diversity of the symbiotic cyanobacterium Synechococcus spongiarum among sponge hosts," Molecular Ecology, vol. 17, no. 12, pp. 29372947, 2008.

[23] E. Gaino, M. Sciscioli, E. Lepore, M. Rebora, and G. Corriero, "Association of the sponge Tethya orphei (Porifera, Demospongiae) with filamentous cyanobacteria," Invertebrate Biology, vol. 125, no. 4, pp. 281-287, 2006.

[24] G. G. Harrigan and G. Goetz, "Symbiotic and dietary marine microalgae as a source of bioactive molecules-experience from natural products research," Journal of Applied Phycology, vol. 14, no. 2, pp. 103-108, 2002.

[25] P. Proksch, R. A. Edrada, and R. Ebel, "Drugs from the seascurrent status and microbiological implications," Applied Microbiology and Biotechnology, vol. 59, no. 2-3, pp. 125-134, 2002.

[26] R. W. Thacker and S. Starnes, "Host specificity of the symbiotic cyanobacterium Oscillatoria spongeliae in marine sponges, Dysidea spp," Marine Biology, vol. 142, no. 4, pp. 643-648, 2003. 
[27] S. Golubic, T. Le Campion-Alsumard, and S. E. Campbell, "Diversity of marine cyanobacteria," in Marine Cyanobacteria, L. Charpy and A. W. D. Larkum, Eds., vol. 19, pp. 53-76, Monaco Musée Océanographique, Monaco, 1999.

[28] M. Yamamuro, "Importance of epiphytic cyanobacteria as food sources for heterotrophs in a tropical seagrass bed," Coral Reefs, vol. 18, no. 3, pp. 263-271, 1999.

[29] H. Iizumi and M. Yamamuro, "Nitrogen fixation activity by periphytic blue-green algae in a seagrass bed on the great barrier reef," Japan Agricultural Research Quarterly, vol. 34, no. 1, pp. 69-73, 2000.

[30] J. M. Hackney, R. C. Carpenter, and W. H. Adey, "Characteristic adaptations to grazing among algal turfs on a Caribbean coral reef," Phycologia, vol. 28, no. 1, pp. 109-119, 1989.

[31] S. Le Bris, T. Le Campion-Alsumard, and J. C. Romano, "Characteristics of epilithic and endolithic algal turf exposed to different levels of bioerosion in French Polynesian coral reefs," Oceanologica Acta, vol. 21, no. 5, pp. 695-708, 1998.

[32] R. M. M. Abed, S. Golubic, F. Garcia-Pichel, G. F. Camoin, and S. Sprachta, "Characterization of microbialite-forming cyanobacteria in a tropical lagoon: Tikehau Atoll, Tuamotu, French Polynesia," Journal of Phycology, vol. 39, no. 5, pp. 862-873, 2003.

[33] L. Charpy, R. Alliod, M. Rodier, and S. Golubic, "Benthic nitrogen fixation in the SW New Caledonia lagoon," Aquatic Microbial Ecology, vol. 47, no. 1, pp. 73-81, 2007.

[34] K. Bauer, B. Díez, C. Lugomela, S. Seppälä, A. J. Borg, and B. Bergman, "Variability in benthic diazotrophy and cyanobacterial diversity in a tropical intertidal lagoon," FEMS Microbiology Ecology, vol. 63, no. 2, pp. 205-221, 2008.

[35] V. J. Paul, R. W. Thacker, K. Banks, and S. Golubic, "Benthic cyanobacterial bloom impacts the reefs of South Florida (Broward County, USA)," Coral Reefs, vol. 24, no. 4, pp. 693697, 2005.

[36] L. Charpy, K. A. Palinska, B. Casareto et al., "Dinitrogenfixing cyanobacteria in microbial mats of two shallow coral reef ecosystems," Microbial Ecology, vol. 59, no. 1, pp. 174186, 2010.

[37] I. Berman-Frank, P. Lundgren, and P. Falkowski, "Nitrogen fixation and photosynthetic oxygen evolution in cyanobacteria," Research in Microbiology, vol. 154, no. 3, pp. 157-164, 2003.

[38] C. Charpy-Roubaud, L. Charpy, and A. Larkum, "Atmospheric dinitrogen fixation by benthic communities of Tikehau lagoon (Tuamotu Archipelago, French Polynesia) and its contribution to benthic primary production," Marine Biology, vol. 139, no. 5, pp. 991-997, 2001.

[39] P. Hallock, "Global change and modern coral reefs: new opportunities to understand shallow-water carbonate depositional processes," Sedimentary Geology, vol. 175, no. 1-4, pp. 19-33, 2005.

[40] S. Albert, J. M. O’Neil, J. W. Udy, K. S. Ahern, C. M. O'Sullivan, and W. C. Dennison, "Blooms of the cyanobacterium Lyngbya majuscula in coastal Queensland, Australia: disparate sites, common factors," Marine Pollution Bulletin, vol. 51, no. 1-4, pp. 428-437, 2005.

[41] D. G. Nagle and V. J. Paul, "Chemical defense of a marine cyanobacterial bloom," Journal of Experimental Marine Biology and Ecology, vol. 225, no. 1, pp. 29-38, 1998.

[42] I. B. Kuffner, L. J. Walters, M. A. Becerro, V. J. Paul, R. RitsonWilliams, and K. S. Beach, "Inhibition of coral recruitment by macroalgae and cyanobacteria," Marine Ecology Progress Series, vol. 323, pp. 107-117, 2006.
[43] E. A. Titlyanov, I. M. Yakovleva, and T. V. Titlyanova, "Interaction between benthic algae (Lyngbya bouillonii, Dictyota dichotoma) and scleractinian coral Porites lutea in direct contact," Journal of Experimental Marine Biology and Ecology, vol. 342, no. 2, pp. 282-291, 2007.

[44] P. Garrett and H. Ducklow, "Coral diseases in Bermuda," Nature, vol. 253, no. 5490, pp. 349-350, 1975.

[45] W. H. Wilson, A. L. Dale, J. E. Davy, and S. K. Davy, "An enemy within? Observations of virus-like particles in reef corals," Coral Reefs, vol. 24, no. 1, pp. 145-148, 2005.

[46] S. K. Davy, S. G. Burchett, A. L. Dale et al., "Viruses: agents of coral disease?" Diseases of Aquatic Organisms, vol. 69, no. 1, pp. 101-110, 2006.

[47] F. Rohwer and R. V. Thurber, "Viruses manipulate the marine environment," Nature, vol. 459, no. 7244, pp. 207-212, 2009.

[48] R. G. Carlton and L. L. Richardson, "Oxygen and sulfide dynamics in a horizontally migrating cyanobacterial mat: black band disease of corals," FEMS Microbiology Ecology, vol. 18, no. 2, pp. 155-162, 1995.

[49] M. Sussman, D. G. Bourne, and B. L. Willis, "A single cyanobacterial ribotype is associated with both red and black bands on diseased corals from Palau," Diseases of Aquatic Organisms, vol. 69, no. 1, pp. 111-118, 2006.

[50] D. Rasoulouniriana, N. Siboni, B. D. Eitan, K. W. Esti, Y. Loya, and A. Kushmaro, "Pseudoscillatoria coralii gen. nov., sp. nov., a cyanobacterium associated with coral black band disease (BBD)," Diseases of Aquatic Organisms, vol. 87, no. 12, pp. 91-96, 2009.

[51] L. L. Richardson and K. G. Kuta, "Ecological physiology of the black band disease cyanobacterium Phormidium corallyticum," FEMS Microbiology Ecology, vol. 43, no. 3, pp. 287-298, 2003.

[52] L. L. Richardson, A. W. Miller, E. Broderick et al., "Sulfide, microcystin, and the etiology of black band disease," Diseases of Aquatic Organisms, vol. 87, no. 1-2, pp. 79-90, 2009.

[53] D. Stanić, S. Oehrle, M. Gantar, and L. L. Richardson, "Microcystin production and ecological physiology of Caribbean black band disease cyanobacteria," Environmental Microbiology, vol. 13, no. 4, pp. 900-910, 2011.

[54] I. B. Kuffner and V. J. Paul, "Effects of the benthic cyanobacterium Lyngbya majuscula on larval recruitment of the reef corals Acropora surculosa and Pocillopora damicornis," Coral Reefs, vol. 23, no. 3, pp. 455-458, 2004.

[55] J. M. O'Neil, “Grazer interactions with nitrogen-fixing marine Cyanobacteria: adaptation for $\mathrm{N}$ - acquisition?" in Marine Cyanobacteria, L. Charpy and A. W. D. Larkum, Eds., vol. 19, pp. 293-317, Monaco Musée Océanographique, Monaco, 1999.

[56] D. W. Klumpp and N. V. C. Polunin, "Partitioning among grazers of food resources within damselfish territories on a coral reef," Journal of Experimental Marine Biology and Ecology, vol. 125, no. 2, pp. 145-169, 1989.

[57] M. J. Marnane and D. R. Bellwood, "Marker technique' for investigating gut throughput rates in coral reef fishes," Marine Biology, vol. 129, no. 1, pp. 15-22, 1997.

[58] C. R. Wilkinson and P. W. Sammarco, "Nitrogen fixation on a coral reef: effects of fish grazing and damselfish territoriality. The Reef and Man," in Proceedings of the 4th International Coral Reef Symposium, p. 589, 1981.

[59] R. W. Thacker, D. G. Nagle, and V. J. Paul, "Effects of repeated exposures to marine cyanobacterial secondary metabolites on feeding by juvenile rabbitfish and parrotfish," Marine Ecology Progress Series, vol. 147, no. 1-3, pp. 21-29, 1997. 
[60] R. W. Thacker, D. W. Ginsburg, and V. J. Paul, "Effects of herbivore exclusion and nutrient enrichment on coral reef macroalgae and cyanobacteria," Coral Reefs, vol. 19, no. 4, pp. 318-329, 2001.

[61] E. Cruz-Rivera and V. J. Paul, "Feeding by coral reef mesograzers: algae or cyanobacteria?" Coral Reefs, vol. 25, no. 4, pp. 617-627, 2006.

[62] E. Cruz-Rivera and V. J. Paul, "Chemical deterrence of a cyanobacterial metabolite against generalized and specialized grazers," Journal of Chemical Ecology, vol. 33, no. 1, pp. 213217, 2007.

[63] V. J. Paul, K. E. Arthur, R. Ritson-Williams, C. Ross, and K. Sharp, "Chemical defenses: from compounds to communities," Biological Bulletin, vol. 213, no. 3, pp. 226-251, 2007.

[64] D. G. Nagle and V. J. Paul, "Production of secondary metabolites by filamentous tropical marine cyanobacteria: ecological functions of the compounds," Journal of Phycology, vol. 35, no. 6, pp. 1412-1421, 1999.

[65] K. Sharp, K. E. Arthur, L. Gu et al., "Phylogenetic and chemical diversity of three chemotypes of bloom-forming Lyngbya species (cyanobacteria: Oscillatoriales) from reefs of southeastern Florida," Applied and Environmental Microbiology, vol. 75, no. 9, pp. 2879-2888, 2009.

[66] A. Capper and V. J. Paul, "Grazer interactions with four species of Lyngbya in southeast Florida," Harmful Algae, vol. 7, no. 6, pp. 717-728, 2008.

[67] A. Méjean, C. Peyraud-Thomas, A. S. Kerbrat et al., "First identification of the neurotoxin homoanatoxin-a from mats of Hydrocoleum lyngbyaceum (marine cyanobacterium) possibly linked to giant clam poisoning in New Caledonia," Toxicon, vol. 56, no. 5, pp. 829-835, 2010.

[68] T. E. Bowman and L. J. Lancaster, "A bloom of the planktonic blue-green alga, Trichodesmium erythraeum, in the Tonga Islands," Limnology and Oceanography, vol. 10, pp. 291-292, 1965.

[69] Y. I. Sorokin, "Phytoplankton and planktonic microflora in the coral reef ecosystem," Journal of General Biology, vol. 40, pp. 677-688, 1979.

[70] N. Revelante and M. Gilmartin, "Dynamics of phytoplankton in the great barrier reef lagoon," Journal of Plankton Research, vol. 4, no. 1, pp. 47-76, 1982.

[71] G. B. Jones, C. Burdon-Jones, and F. G. Thomas, "Influence of Trichodesmium red tides on trace metal cycling at a coastal station in the Great Barrier Reef Lagoon," in the International Symposium on Coastal Lagoons, pp. 319-326, Bordeaux, France, 1982.

[72] P. R. F. Bell, "Status of eutrophication in the Great Barrier Reef Lagoon," Marine Pollution Bulletin, vol. 23, pp. 89-93, 1991.

[73] I. Muslim and G. Jones, "The seasonal variation of dissolved nutrients, chlorophyll a and suspended sediments at Nelly Bay, Magnetic Island," Estuarine, Coastal and Shelf Science, vol. 57, no. 3, pp. 445-455, 2003.

[74] V. Cheevaporn and P. Menasveta, "Water pollution and habitat degradation in the Gulf of Thailand," Marine Pollution Bulletin, vol. 47, no. 1-6, pp. 43-51, 2003.

[75] C. Dupouy, M. Petit, and Y. Dandonneau, "Satellite detected cyanobacteria bloom in the southwestern tropical Pacific: implication for oceanic nitrogen fixation," International Journal of Remote Sensing, vol. 9, no. 3, pp. 389-396, 1988.

[76] V. P. Devassy, P. M. A. Bhattathiri, and S. Z. Qasim, "Succession of organisms following trichodesmium phenomenon," Indian Journal of Marine Sciences, vol. 8, pp. 89-93, 1979.
[77] S. P. Hawser, G. A. Codd, D. G. Capone, and E. J. Carpenter, "A neurotoxic factor associated with the bloom-forming cyanobacterium Trichodesmium," Toxicon, vol. 29, no. 3, pp. 277-278, 1991.

[78] S. P. Hawser, J. M. O’Neil, M. R. Roman, and G. A. Codd, "Toxicity of blooms of the cyanobacterium Trichodesmium to zooplankton," Journal of Applied Phycology, vol. 4, no. 1, pp. 79-86, 1992.

[79] J. M. O’Neil and M. R. Roman, “Ingestion of the cyanobacterium Trichodesmium spp. by pelagic harpacticoid copepods Macrosetella, Miracia and Oculosetella," in Ecology and Morphology of Copepods, F. D. Ferrari and B. P. Bradley, Eds., vol. 292-293, pp. 235-240, Kluwer Academic Publishers, Dordrecht, The Netherlands, 1994.

[80] C. Guo and P. A. Tester, "Toxic effect of the bloom-forming Trichodesmium sp. (Cyanophyta) to the copepod Acartia tonsa," Natural Toxins, vol. 2, no. 4, pp. 222-227, 1994.

[81] A. P. Negri, O. Bunter, B. Jones, and L. Llewellyn, "Effects of the bloom-forming alga Trichodesmium erythraeum on the pearl oyster Pinctada maxima," Aquaculture, vol. 232, no. 14, pp. 91-102, 2004.

[82] A. S. Kerbrat, H. T. Darius, S. Pauillac, M. Chinain, and D. Laurent, "Detection of ciguatoxin-like and paralysing toxins in Trichodesmium spp. from New Caledonia lagoon," Marine Pollution Bulletin, vol. 61, no. 7-12, pp. 360-366, 2010.

[83] D. Karl, A. Michaels, B. Bergman et al., "Dinitrogen fixation in the world's oceans," Biogeochemistry, vol. 57-58, pp. 47-98, 2002.

[84] C. Lugomela, T. J. Lyimo, I. Bryceson, A. K. Semesi, and B. Bergman, "Trichodesmium in coastal waters of Tanzania: diversity, seasonality, nitrogen and carbon fixation," Hydrobiologia, vol. 477, pp. 1-13, 2002.

[85] J. M. O'Neil, P. M. Metzler, and P. M. Glibert, "Ingestion of super 15N2-labelled Trichodesmium spp. and ammonium regeneration by the harpacticoid copepod Macrosetella gracilis," Marine Biololgy, vol. 125, pp. 89-96, 1996.

[86] T. A. Villareal, "Abundance and photosynthetic characteristics of Trichodesmium spp. along the Atlantic Barrier Reef at Carrie Bow Cay, Belize," Marine Ecology, vol. 16, no. 3, pp. 259-271, 1995.

[87] L. Charpy, J. Blanchot, and L. Lo, "Cyanobacteria Synechococcus spp. contribution to primary production in a closed atoll lagoon (Takapoto, Tuamotu, French polynesia)," Comptes Rendus de l'Academie des Sciences - Serie III, vol. 314, no. 9, pp. 395-401, 1992.

[88] L. Charpy and J. Blanchot, "Prochlorococcus contribution to phytoplankton biomass and production of Takapoto atoll (Tuamotu archipelago)," Comptes Rendus de l'Academie des Sciences - Serie III, vol. 319, no. 2, pp. 131-137, 1996.

[89] L. Charpy and J. Blanchot, "Photosynthetic picoplankton in French Polynesian atoll lagoons: estimation of taxa contribution to biomass and production by flow cytometry," Marine Ecology Progress Series, vol. 162, pp. 57-70, 1998.

[90] L. Charpy and J. Blanchot, "Picophytoplankton biomass, community structure and productivity in the Great Astrolabe lagoon, Fiji," Coral Reefs, vol. 18, no. 3, pp. 255-262, 1999.

[91] B. E. Casareto, Y. Suzuki, K. Fukami, and Y. Yoshida, "Particulate organic carbon budget and flux in a fringing coral reef at Liyako Island, Okinawa, Japan in July 1996," in Proceedings of the 9th International Coral Reef Symposium, vol. 1, pp. 95100, Bali, Indonesia, 2002.

[92] N. D. Crosbie and M. J. Furnas, "Abundance, distribution and flow-cytometric characterization of picophytoprokaryote 
populations in central $(17 \circ S)$ and southern $(20 \circ S)$ shelf waters of the Great Barrier Reef," Journal of Plankton Research, vol. 23, no. 8, pp. 809-828, 2001.

[93] N. D. Crosbie and M. J. Furnas, "Net growth rates of picocyanobacteria and nano-/microphytoplankton inhabiting shelf waters of the central $(17 \circ$ S) and southern $(20 \circ$ S) Great Barrier Reef," Aquatic Microbial Ecology, vol. 24, no. 3, pp. 209-224, 2001.

[94] L. Charpy, "Importance of photosynthetic picoplankton in coral reef ecosystems," Vie et Milieu, vol. 55, no. 3-4, pp. 217 223, 2005.

[95] Y. Thomas, P. Garen, C. Courties, and L. Charpy, "Spatial and temporal variability of the pico- and nanophytoplankton and bacterioplankton in a deep Polynesian atoll lagoon," Aquatic Microbial Ecology, vol. 59, no. 1, pp. 89-101, 2010.

[96] C. Ferrier-Pagès and P. Furla, "Pico- and nanoplankton biomass and production in the two largest atoll lagoons of French Polynesia," Marine Ecology Progress Series, vol. 211, pp. 63-76, 2001.

[97] L. Charpy, "Phytoplankton biomass and production in two tuamotu atoll lagoons (French polynesia)," Marine Ecology Progress Series, vol. 145, no. 1-3, pp. 133-142, 1996.

[98] B. E. Casareto, L. Charpy, J. Blanchot, Y. Suzuki, K. Kurosawa, and Y. Ishikawa, "Phototrophic prokaryotes in Bora Bay, Miyako Island, Okinawa, Japan," in Proceedings of the 10th International Coral Reef Symposium, vol. 1, pp. 844-853, Okinawa, Japan, 2006.

[99] T. Ayukai, "Picoplankton dynamics in davies Reeflagoon, the great barrier reef, Australia," Journal of Plankton Research, vol. 14, no. 11, pp. 1593-1606, 1992.

[100] K. Tada, K. Sakai, Y. Nakano, A. Takemura, and S. Montani, "Size-fractionated phytoplankton biomass in coral reef waters off Sesoko Island, Okinawa, Japan," Journal of Plankton Research, vol. 25, no. 8, pp. 991-997, 2003.

[101] C. Ferrier-Pagès and J. P. Gattuso, "Biomass, production and grazing rates of pico- and nanoplankton in coral reef waters (Miyako Island, Japan)," Microbial Ecology, vol. 35, no. 1, pp. 46-57, 1998.

[102] F. Houlbrèque, B. Delesalle, J. Blanchot, Y. Montel, and C. Ferrier-Pagès, "Picoplankton removal by the coral reef community of La Prévoyante, Mayotte Island," Aquatic Microbial Ecology, vol. 44, no. 1, pp. 59-70, 2006.

[103] I. C. Biegala and P. Raimbault, "High abundance of diazotrophic picocyanobacteria $(<3 \mu \mathrm{m})$ in a Southwest Pacific coral lagoon," Aquatic Microbial Ecology, vol. 51, no. 1, pp. 45-53, 2008.

[104] J. M. González, J.-P. Torréton, P. Dufour, and L. Charpy, "Temporal and spatial dynamics of the pelagic microbial food web in an atoll lagoon," Aquatic Microbial Ecology, vol. 16, no. 1, pp. 53-64, 1998.

[105] A. Sakka, L. Legendre, M. Gosselin, and B. Delesalle, "Structure of the oligotrophic planktonic food web under low grazing of heterotrophic bacteria: Takapoto Atoll, French Polynesia," Marine Ecology Progress Series, vol. 197, pp. 1-17, 2000.

[106] A. J. Pile, "Finding Reiswig's missing carbon: quantification of sponge feeding using dual-beam flow cytometry," in Proceeding 8th International Coral Reef Symposium, vol. 2, pp. 1403-1410, 1997.

[107] G. Yahel, A. F. Post, K. Fabricius, D. Marie, D. Vaulot, and A. Genin, "Phytoplankton distribution and grazing near coral reefs," Limnology and Oceanography, vol. 43, no. 4, pp. 551$563,1998$.
[108] G. Yahel, J. H. Sharp, D. Marie, C. Häse, and A. Genin, "In situ feeding and element removal in the symbiont-bearing sponge Theonella swinhoei: Bulk DOC is the major source for carbon," Limnology and Oceanography, vol. 48, no. 1, pp. 141-149, 2003.

[109] M. Ribes, R. Coma, and J. M. Gili, "Heterotrophic feeding by gorgonian corals with symbiotic zooxanthella," Limnology and Oceanography, vol. 43, no. 6, pp. 1170-1179, 1998. 

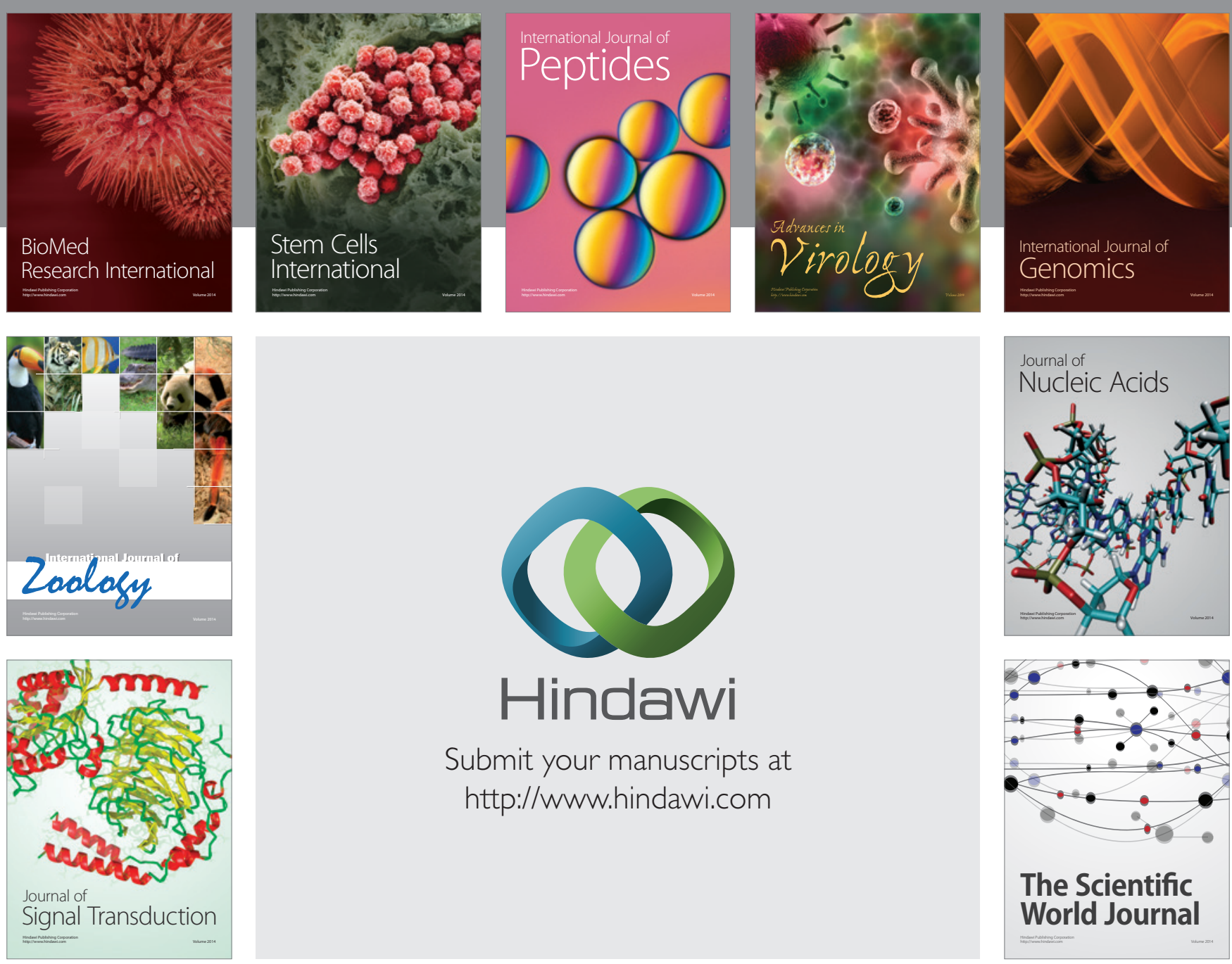

Submit your manuscripts at

http://www.hindawi.com
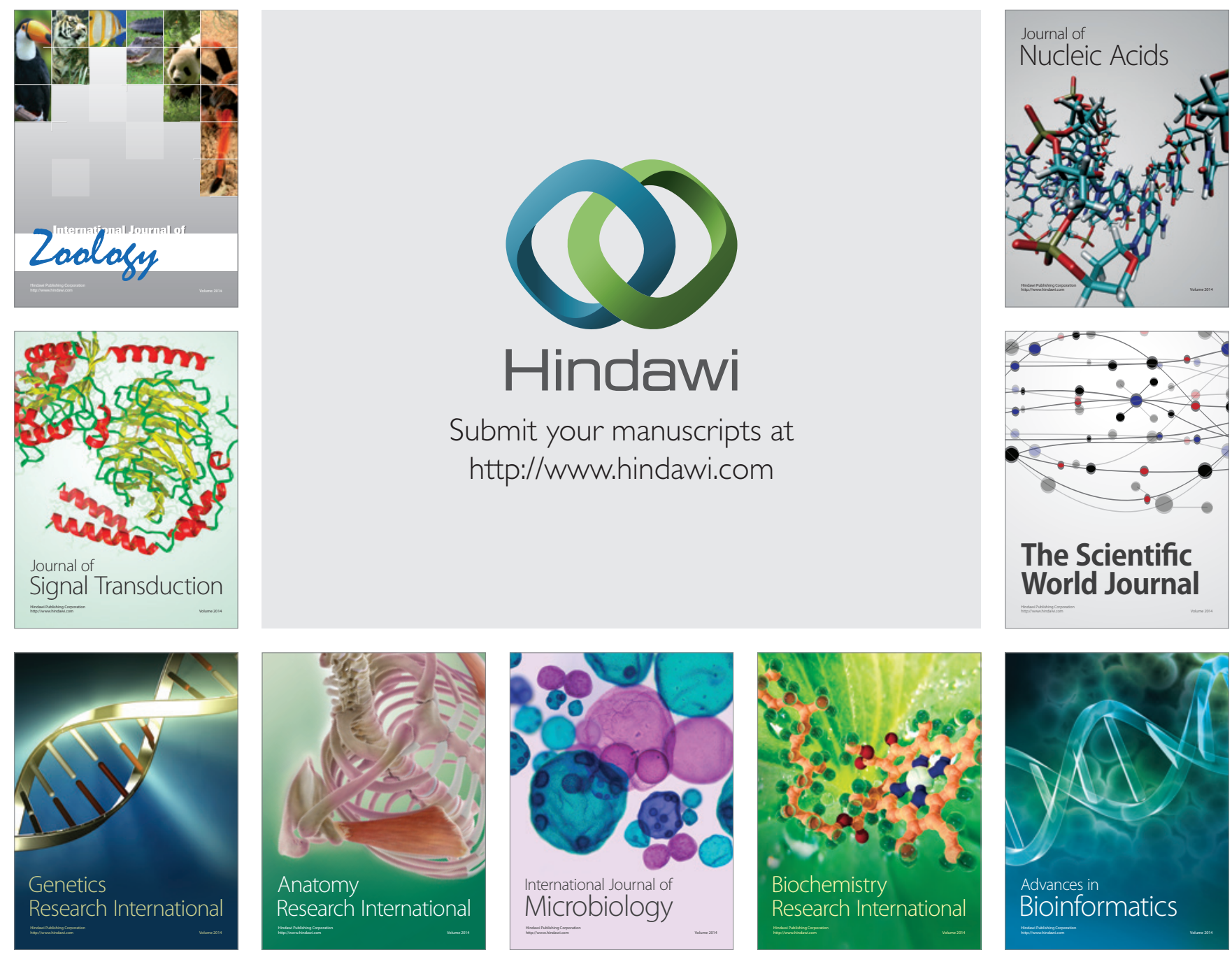

The Scientific World Journal
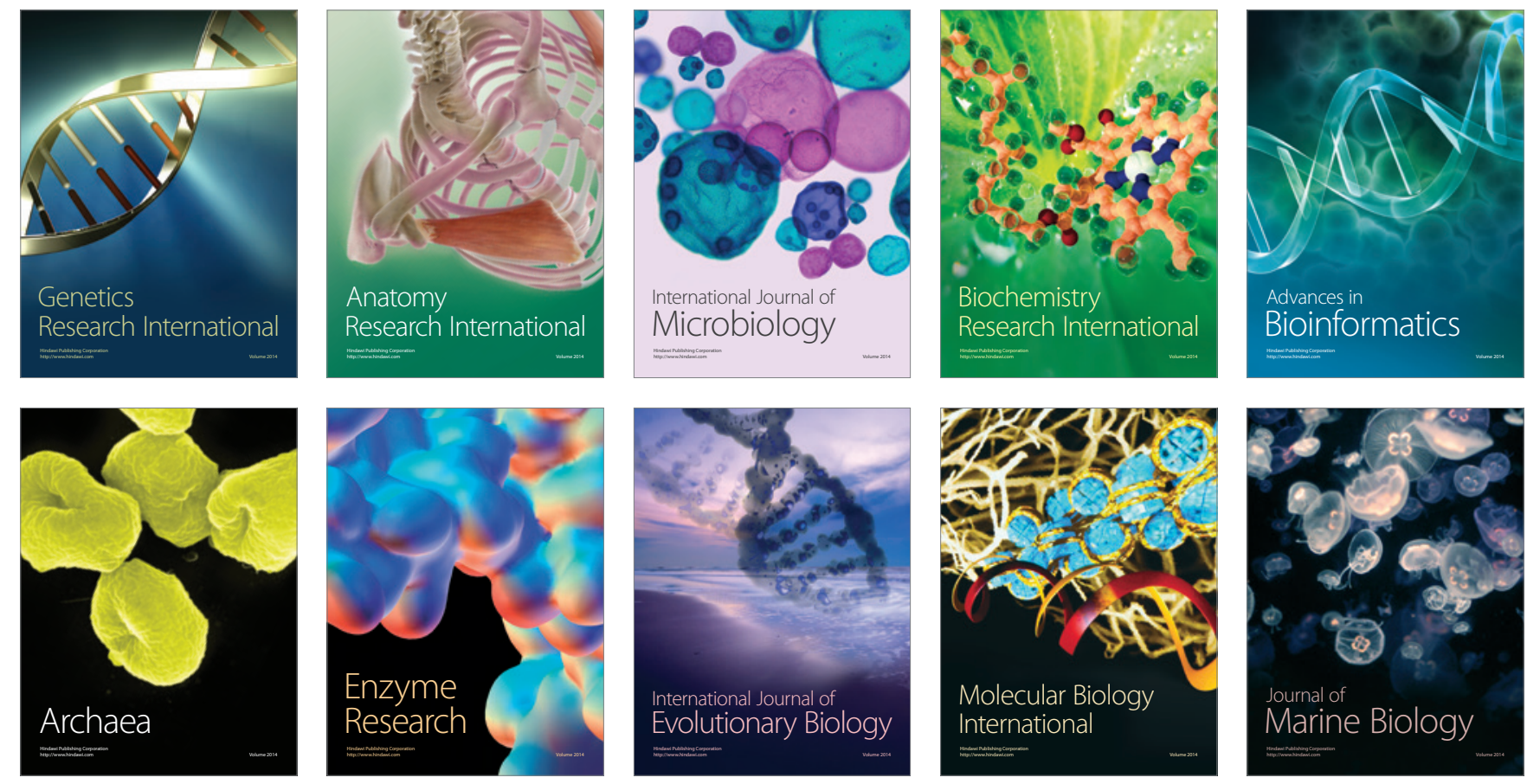